\title{
ANALISIS DAN SIMULASI \\ DYNAMIC MOVEMENT-BASED LOCATION-UPDATING SCHEME (MBLS) PADA JARINGAN KOMUNIKASI BERGERAK
}

\author{
Ariati Diah Wardhany ${ }^{1}$, Nurain Silalahi ${ }^{2}$, Nachwan Mufti Adriansyah ${ }^{3}$ \\ Jurusan Teknik Elektro Sekolah Tinggi Teknologi Telkom, Bandung \\ 1ariati_diah@telkom.net, ${ }^{2}$ nurain@bdg.centrin.net.id, ${ }^{3}$ nma@stttelkom.ac.id
}

\begin{abstract}
Abstrak
Dalam jaringan komunikasi bergerak, proses signaling yang bukan berasal dari sebuah panggilan juga mempengaruhi beban signaling pada jaringan. Proses signaling tersebut disebut non call related signaling. Pada dasarnya non call related signaling digunakan untuk memantau posisi Mobile Station (MS). Database yang efisien dan manajemen lokasi yang baik dibutuhkan untuk memenuhi kondisi pengguna yang semakin banyak dan dengan mobilitas yang semakin tinggi. Location updating dinamik merupakan suatu konsep location updating yang prosesnya dijalankan sesuai kelakuan pengguna, yaitu pergerakan pengguna dan pola datangnya panggilan kepada pengguna. Dynamic Movement Based Location Updating (MBLS) merupakan salah satu strategi location updating dinamik untuk mencapai pembebanan jaringan yang optimal. Beban optimal adalah jumlah beban location updating dan paging yang memberikan suatu nilai beban paling kecil. Dalam implementasinya, pengguna harus mempunyai suatu counter dalam terminal mobile-nya (MT) untuk menghitung jumlah sel yang sudah dilewatinya. Jika pengguna sudah mencapai batas/threshold sel yang harus dilewati, maka pengguna tersebut berinisiatif melakukan update lokasi ke sistem. Akan ditunjukkan juga metode location updating kombinasi yang merupakan gabungan dari dua skema dinamik yaitu gabungan pergerakan (movement) dan pewaktu (timer). Pada jurnal ini dapat diperlihatkan bahwa perubahan parameter-parameter kelakuan pengguna akan mempengaruhi beban location updating MBLS dan kombinasinya.
\end{abstract}

Kata kunci : manajemen lokasi, location updating dinamik, call delivery, kode sel, non call related signaling

\begin{abstract}
In mobile communication network, signaling process coming not from call process influences signaling load of a communication network. This process is called non call related signaling. Basically, this process is used to observe the location of Mobile Station (MS). Efficient database and location management schemes are needed to fulfill the behaviors of user, which are the mobility and calling patterns of the user. MBLS is one of the dynamic locations updating strategy to reach the optimal load in the network. Optimal load is the amount of location updating and paging loads that give the least total cost. For implementations, users have to get a counter in their Mobile Terminal (MT) to count how many cells they have just through. If a counter has reached the threshold value of the movement, users have to initiate a location update process to the network system. A combination of location updating method consisting of two dynamic schemes, i.e. movement and timer, will be sown as well. This journal presents that the change of user behavior parameters would influence the load of location updating (MBLS) and its combinations.
\end{abstract}

Keywords: location management, dynamic location updating, call delivery, cell code, non call related signaling.

\section{Pendahuluan}

Bertambahnya jumlah pengguna (user) memicu operator untuk membuat jaringan agar tetap dapat melayani semua user itu dengan baik, salah satu caranya adalah dengan menerapkan konfigurasi mikrosel atau pikosel. Manajemen lokasi dibutuhkan untuk kondisi jaringan dengan sel mikro atau piko. Manajemen lokasi mencakup proses location updating (LU) dan paging.

Pada titik atau saat kapankah beban optimal dapat di capai oleh sistem? Parameter apa sajakah yang mempengaruhi beban location updating? Beban optimal adalah beban yang terkecil yang dihasilkan sistem.

\section{Konsep Dasar MBLS}

\subsection{Proses Location Updating secara normal}

Setiap sel dilayani oleh satu BTS dan satu area lokasi (LA) terdiri dari satu sel atau lebih. VLR dapat melayani satu atau lebih area lokasi (LA). MS yang tidak aktif akan diabaikan oleh sistem. Pada saat MS mengaktifkan mobile unitnya, maka MS tersebut akan melakukan perbandingan pada LAI (Location Area Identity) yang disimpan pada SIM dengan LAI yang dibroadcast (dipancarkan) oleh sel tempat dia berada saat itu.

Jika LAI tersebut cocok maka MS tidak harus melakukan apapun, tetapi jika tidak cocok maka MS 
tersebut akan mengidentifikasi dirinya dengan mengirimkan IMSI-nya bersama dengan identitas area lokasinya saat itu dan area lokasi sebelumnya. Selanjutnya BSS akan mengirimkan sinyal informasi ini ke VLR.[7]

Protokol yang dipergunakan dalam signaling proses location updating antara lain [7]:

- HLR dengan MSC/VLR

Menggunakan pensinyalan SS7. Protokol aplikasinya menggunakan MAP (Mobile Application Part).

- $\quad$ MSC/VLR dengan MS

Menggunakan protokol RIL3-MM (Radio Interface Layer 3, Mobility Management).

- $\quad$ MS dengan kartu SIM

Protokol sederhana, sebatas perintah baca dan tulis memori.

\subsection{Paging}

Paging dilakukan oleh jaringan bila terdapat suatu panggilan ke pelanggan. Sinyal paging dtransmisikan kepada sel-sel yang diduga sebagai tempat MS berada. Semua MS pada sel-sel tersebut akan mendengar sinyal paging dan hanya MS yang dituju saja yang akan mengirimkan sinyal respon pada arah uplink. Proses untuk pencarian lokasi MS dengan menebarkan sinyal paging disebut sebagai Polling cycle.[7][3]

Karena paging menggunakan bandwidth yang cukup lebar, maka harus dipilih strategi agar proses paging tidak terlalu boros dalam pensinyalannya, sehingga beban paging tidak terlalu besar. Beban paging akan tergantung pada banyaknya polling cycle yang dilakukan. Jika dalam 1 polling cycle MS tersebut belum ditemukan, maka polling cycle dapat dilakukan lagi. Umumnya BTS akan mengirimkan sinyal paging sebanyak 3 kali ke MS.

Protokol yang dipergunakan untuk prosedur paging melibatkan :

- $\quad$ MSC/VLR dengan BSC

Menggunakan pensinyalan SS7. Protokol aplikasinya menggunakan BSSMAP (BSS Management Application Part).

- $\quad$ BSC dengan BTS

Menggunakan protocol RSM (Radio Subsystem Management) TS 08.05.

- $\quad$ BTS dengan MS

Menggunakan protocol RIL3-RR (Radio Interface Layer 3-Radio Resource)

\section{Skema Location Update Dinamik Berdasarkan Pergerakan (MBLS)}

\subsection{Pemodelan dan deskripsi sistem}

Diasumsikan jaringan PCS mempunyai area layanan yang terbagi menjadi sel-sel berukuran mikro. Proses Location updating dipicu jika MS sudah melewati sejumlah sel yang sama dengan nilai threshold (batas) yang diset pada MT (mobile terminal) jika diukur dari posisi terakhir MS tersebut mengupdate lokasinya. Posisi terakhir MS yang diketahui sistem dinamakan sel pusat (center cell) dimana sel tersebut akan menentukan area yang akan di-paging jika ada panggilan datang ke suatu MS. Area paging yang dimaksud adalah area yang mencakup sel-sel yang mengelilingi posisi terakhir MS sejauh (d) keliling (ring $(d)$ ). [4][3].

Jumlah sel yang di-paging dalam satu kali panggilan adalah:

$$
1+\sum_{n=1}^{n=d} 6 n
$$

sebagaimana diperlihatkan pada Gambar 1.

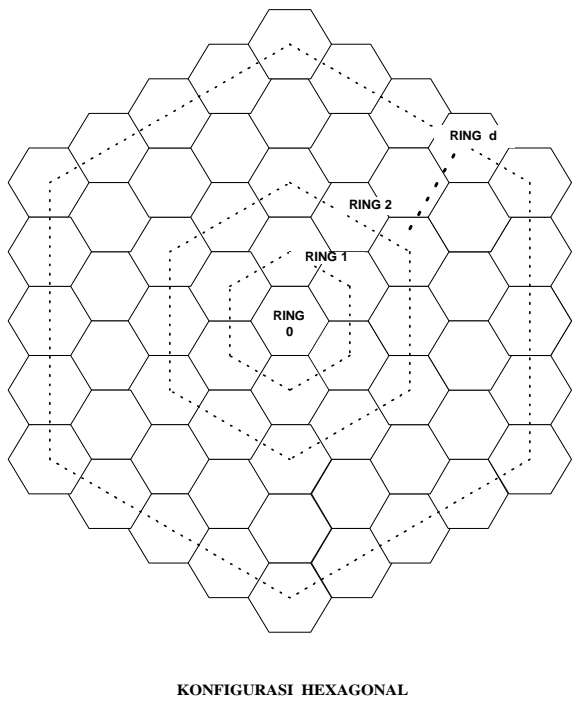

Gambar 1. Area paging berdasarkan Konsep Ring

\subsection{Beban Location Update}

Beban Location Update pada jaringan adalah jumlah proses location update yang dilakukan oleh sistem. Penggunaan bandwidth pada transmisi (signaling) dan proses komputasi pada database memerlukan energi cukup besar ketika proses LU tersebut dilakukan.

a. Pada skema dinamik (pergerakan) MBLS dibutuhkan suatu perangkat tambahan pada unit mobile terminal (MT), yaitu berupa sebuah counter. Counter tersebut akan menghitung jumlah sel yang sudah dilewati oleh MS. Jika nilai counter tersebut sudah mencapai nilai thresholdnya (d), maka MS tersebut berinisiatif melakukan proses location updating.[4]

\section{Location updating $\rightarrow$ Counter $(n)=d$ threshold}

b. Pada skema Kombinasi, counter pewaktu (timer) dijalankan bersamaan dengan counter penghitung sel (MBLS). Nilai timer ini tentunya juga akan mempengaruhi beban LU yang dihasilkan. Nilai timer optimal tidak di perhitungkan dalam penelitian ini. Penelitian ini 
akan menunjukkan pengaruh timer tersebut. Syarat location updating dari metode kombinasi ini adalah :

\section{Counter $(n) \neq d$ threshold Counter $(t)=$ th}

c. Pada proses call set up atau panggilan datang (incoming call), terlebih dahulu sistem akan meminta identitas dari si pemanggil, otomatis nomor identitas pelanggan dan lokasi pelanggan tersebut diketahui. Karena itu, jika proses call set up ataupun panggilan datang, maka counter dari pelanggan tersebut akan di reset sampai proses pendudukan berakhir [3].

\subsection{Beban Paging}

Beban paging dihitung dari jumlah sel yang harus dibroadcast setiap terjadi panggilan. Sinyal paging yang dibroadcast diasumsikan hanya dilakukan 1 kali polling cycle.Sel yang dibroadcast hanyalah sel yang berada dalam satu area layanan .

\section{Analisa Regresi}

Tujuan dari regresi adalah untuk mengetahui hubungan antara satu variabel dengan variabel lain. Variabel bebas adalah nilai threshold(d), sedangkan variabel terikat adalah beban LU dan paging. Asumsi terhadap pola data yang dihasilkan oleh masing-masing beban harus ditentukan dulu pada sebuah fungsi. Pola data yang diambil sebaiknya adalah pola data yang mempunyai nilai R-Square paling tinggi. R-square adalah nilai yang merepresentasikan besarnya konstribusi variabel bebas (x) terhadap naik/turunnya variabel terikat (y).

Kecenderungan data untuk beban paging adalah linier dan untuk beban LU adalah kuasa (power). Beban paging diasumsikan untuk semua titik pengamatan $\left(x_{i}, y_{i}\right)$ berada pada grafik linier maka semua $n$ titik pengamatan memenuhi hubungan

$$
y_{i}=a+b x_{i}+e_{i}
$$

$e_{i}$ adalah kesalahan pengganggu (disturbance error). Nilai $a$ dan $b$ akan dicari sehingga jumlah kesalahan kuadrat menjadi minimum. Cara ini disebut metode kuadrat terkecil. Jadi $a$ dan $b$ akan dicari sehingga meminimumkan $e_{i}$.

Begitu juga dengan beban LU dimana untuk semua $n$ titik pengamatan memenuhi hubungan :

$$
y=a x^{b}+e
$$

Dengan metode kuadrat terkecil pula, maka nilai $a$ dan $b$ dapat dicari.

\section{Parameter-Parameter yang Mempengaruhi Beban Location Updating dan Paging}

Perubahan parameter akan menyebabkan kondisi/nilai total beban berkurang atau bertambah. Dari perubahan-perubahan tersebut akan dilihat pola data yang dihasilkan. Data tersebut nantinya akan di normalisir dengan nilai masing-masing beban maksimum yang dapat ditangani sistem. Nilai beban tersebut akan dilihat polanya lalu dicari fungsi regresinya dan keterkaitan beban location updating dan beban paging [5]. Dari grafik beban yang di plot akan dilihat nilai threshold (d) yang menghasilkan beban optimal (minimum).

\subsection{Nilai Threshold (d)}

Nilai threshold menentukan kapan MS harus melakukan updating. Jika nilai d semakin kecil maka beban LU akan semakin besar dan beban paging akan semakin kecil. Nilai Threshold (d) optimal yang didapatkan akan bergantung total beban yang dihasilkan oleh masing-masing beban Location Updating dan beban paging .

\subsection{Radius sel}

Ukuran sel pada sel mikro maksimal berdiameter $1 \mathrm{~km}$. Jelas dengan kecepatan konstan semakin kecil ukuran sel maka proses LU juga akan semakin sering. Semakin kecil radius sel maka beban paging juga akan semakin banyak. Pengaruh radius sel terhadao beban LU ditunjukkan pada Tabel 1 dan Gambar 2.

\begin{tabular}{|c|c|c|c|c|c|c|}
\hline Kasus & $\begin{array}{c}\mathrm{R} \\
(\mathrm{km})\end{array}$ & $\begin{array}{c}\text { Jumlah } \\
\text { MS }\end{array}$ & $\begin{array}{c}\text { Kecepatan } \\
\text { MS } \\
(\mathrm{km} / \mathrm{jam})\end{array}$ & $\begin{array}{l}\text { Panggilan } \\
\text { (call/jam) }\end{array}$ & $\begin{array}{l}\text { Threshold } \\
\text { Optimal } \\
\text { (d) }\end{array}$ & $\begin{array}{l}\text { Total } \\
\text { Cost }\end{array}$ \\
\hline \multirow{4}{*}{1} & \multirow{4}{*}{0.3} & 50 & \multirow{2}{*}{30} & 1 & 3 & 0.484 \\
\hline & & 50 & & 10 & 3 & 0.425 \\
\hline & & 50 & \multirow{2}{*}{40} & 1 & 3 & 0.488 \\
\hline & & 50 & & 10 & 3 & 0.436 \\
\hline \multirow{4}{*}{2} & \multirow{4}{*}{0.5} & 50 & \multirow{2}{*}{30} & 1 & 3 & 0.490 \\
\hline & & 50 & & 10 & 3 & 0.402 \\
\hline & & 50 & \multirow{2}{*}{40} & 1 & 3 & 0.498 \\
\hline & & 50 & & 10 & 3 & 0.430 \\
\hline
\end{tabular}

Tabel 1. Nilai Threshold Optimal untuk Skema MBLS

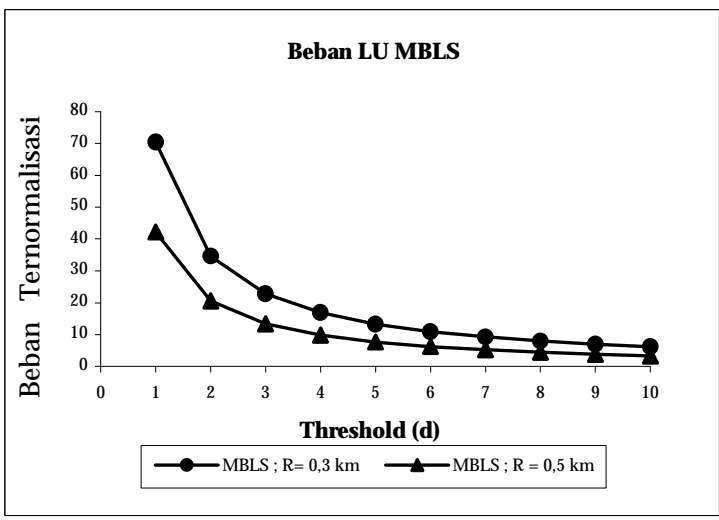

Gambar 2. Grafik Perbandingan Beban LU MBLS pada variasi Radius (tidak ternormalisasi) 


\subsection{Kecepatan MS}

Kecepatan rata-rata MS dalam perkotaan (sel mikro) tidaklah terlalu tinggi. Kecepatan tersebut berkisar antara $40-60 \mathrm{~km} / \mathrm{jam}$. Asumsi pergerakan MS adalah melintas lulus tanpa berhenti maka MS dengan kecepatan lebih tinggi menghasilkan beban LU yang lebih besar. Hasil simulasi tentang pengaruh kecepatan MS terhadap beban LU diperlihatkan pada Gambar 3.

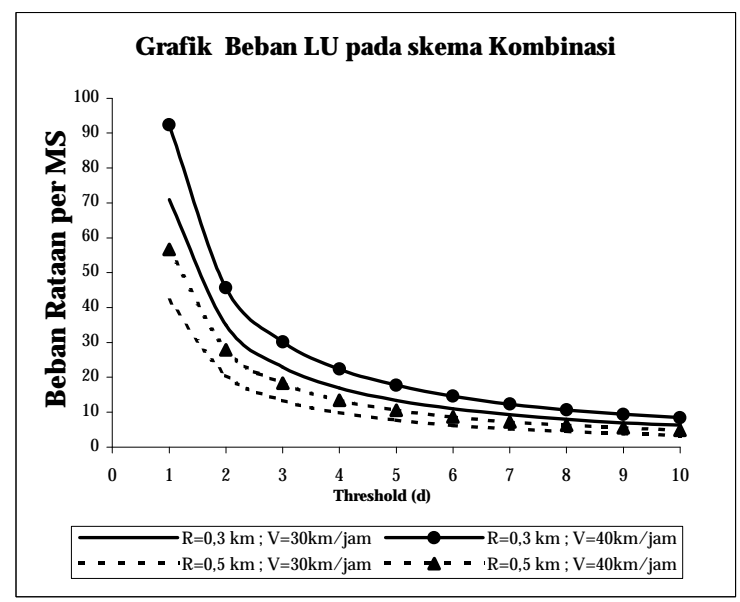

Gambar 3. Grafik Beban Rataan Location Updating dengan variasi nilai $\mathrm{R}$ (radius sel) dan V (tidak tenormalisasi)

\subsection{Kedatangan Panggilan (incoming call)}

Panggilan berpengaruh terhadap counter yang dipakai oleh MS. Jika terjadi panggilan maka counter MS akan di reset[4]. Hal ini disebabkan karena selama proses panggilan berlangsung sistem tersebut pasti mengetahui lokasi MS tersebut [7]. Pada Gambar 4 ditunjukan pengaruh jumlah kedatangan panggilan terhadap beban LU.

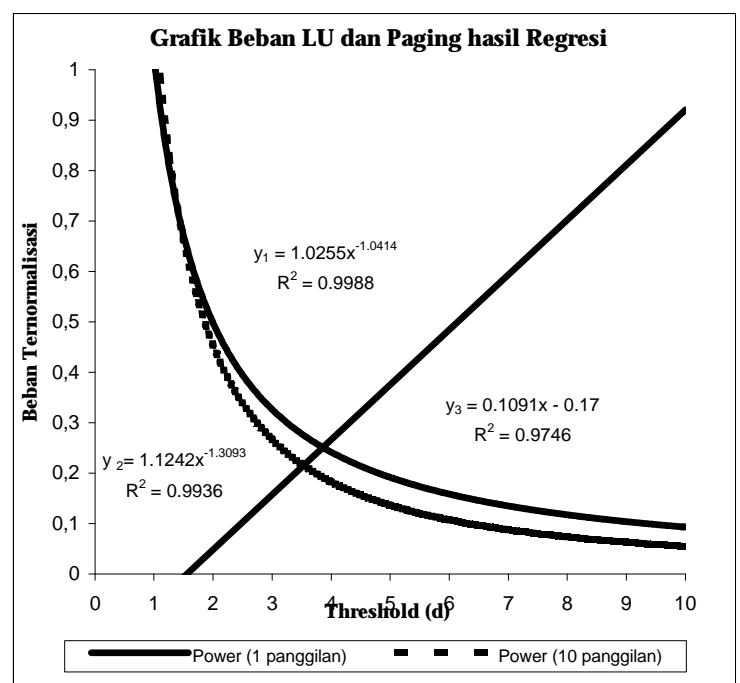

Gambar 4. Grafik Pengaruh jumlah rata-rata panggilan yang diterima MS terhadap beban LU pada $\mathrm{R}=0.3 \mathrm{~km} ; \mathrm{V}=30 \mathrm{~km} / \mathrm{jam}$

\subsection{Timer}

Dengan memakai skema Kombinasi maka kita memadukan skema Location updating berdasar movement (pergerakan) dan timer (waktu). Fungsi Timer disini adalah untuk mengantisipasi bila MS tidak diketahui posisinya/lokasinya dalam jangka waktu yang lama sekali sehingga pemantauan lokasi oleh sistem tidak terputus. Nilai threshold timer disini sangat menentukan beban LU jika timer yang dipakai terlalu pendek misal 5 menit, maka akan menaikkan jumlah/nilai beban LU. Pengaruh nilai threshold timer $(t)$ terhadap beban LU ditunjukkan pada Gambar 5.

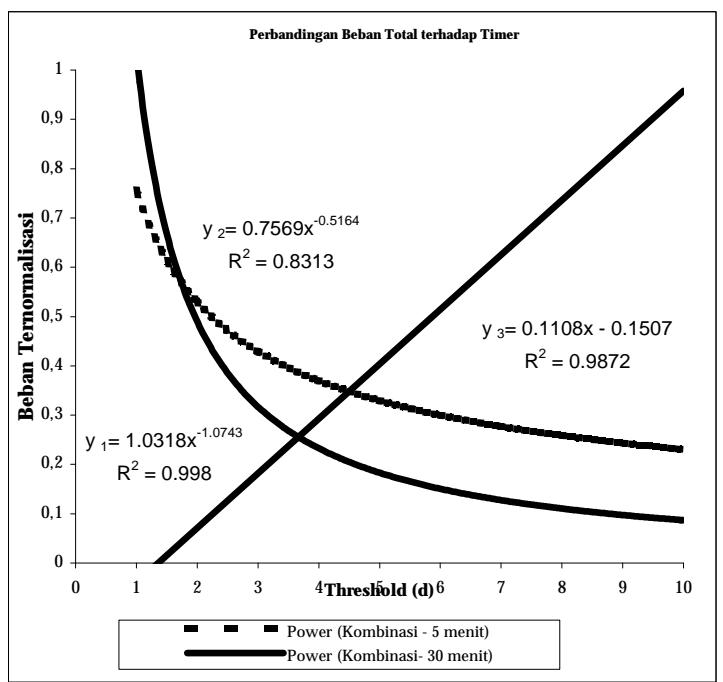

Gambar 5. Grafik Beban LU pada skema Kombinasi dengan Radius sel $=0,5 \mathrm{~km} ; \mathrm{V}=30 \mathrm{~km} / \mathrm{jam}$

\subsection{Nilai Threshold Hasil Regresi}

Gambar 5 memperlihatkan rangkuman nilai threshold optimal berdasarkan hasil simulasi dengan pendekatan regresi. Titik potong yang terjadi diperkirakan akan memberikan beban location updating dan beban paging optimal bagi jaringan.

Tabel 2. Nilai Threshold (d) optimal untuk skema Kombinasi ( timer $=30$ menit $)$

\begin{tabular}{|c|c|c|c|c|c|c|}
\hline Kasus & $\begin{array}{c}\mathrm{R} \\
(\mathrm{km})\end{array}$ & \begin{tabular}{|c|} 
Jumlah \\
MS
\end{tabular} & $\begin{array}{c}\text { Kecepatan MS } \\
(\mathrm{km} / \mathrm{jam})\end{array}$ & $\begin{array}{l}\text { Panggilan } \\
\text { (call/jam) }\end{array}$ & \begin{tabular}{|c|} 
Threshold \\
Optimal (d) \\
\end{tabular} & $\begin{array}{l}\text { Total } \\
\text { Cost } \\
\end{array}$ \\
\hline \multirow{4}{*}{1} & \multirow{4}{*}{0.3} & 50 & \multirow{2}{*}{30} & 1 & 3 & 0.479 \\
\hline & & 50 & & 10 & 3 & 0.433 \\
\hline & & 50 & \multirow{2}{*}{40} & 1 & 3 & 0.488 \\
\hline & & 50 & & 10 & 3 & 0.442 \\
\hline \multirow{4}{*}{2} & \multirow{4}{*}{0.5} & 50 & \multirow{2}{*}{30} & 1 & 3 & 0.489 \\
\hline & & 50 & & 10 & 3 & 0.421 \\
\hline & & 50 & \multirow{2}{*}{40} & 1 & 3 & 0.498 \\
\hline & & 50 & & 10 & 3 & 0.437 \\
\hline
\end{tabular}

\subsection{Beban Total (Total Signalling Cost)}

Total Beban dapat dihitung dari [4]:

Total Beban = Beban LU + Beban Paging 
Pada Tabel 2 terlihat bahwa nilai total beban terkecil terjadi di kasus 2 , yaitu dengan $\mathrm{R}=0,5 \mathrm{~km}$; $\mathrm{V}=30 \mathrm{~km} / \mathrm{jam}$; jumlah panggilan per jam $=10$ panggilan/jam; threshold optimal $\mathrm{d}=3$, sehingga beban totalnya $=0,421$ merupakan nilai terkecil.

\subsection{Improvement}

Perbaikan dilakukan dengan membandingkan total beban antara skema MBLS dan skema kombinasi pada kasus yang sama.

- Total beban skema MBLS $=0.402$

- Total beban skema Kombinasi $=0.421$

- improvement $=\frac{(0,421-0,402)}{0,402} \times 100 \%=4,72 \%$

\section{Kesimpulan}

Berdasarkan analisa dan simulasi MBLS, dapat disimpulkan bahwa kenaikan beban LU dipengaruhi oleh radius sel, kecepatan MS yang tinggi, dan jumlah panggilan yang diterima atau dilakukan. Total beban terkecil terjadi pada kondisi $\mathrm{R}=0,5 \mathrm{~km}$; $\mathrm{V}=30 \mathrm{~km} / \mathrm{jam}$; jumlah panggilan $=10$ panggilan $/$ jam. Nilai Beban Optimal pada tiap kasus terjadi bila nilai threshold (d) sama dengan 3 sel. Total beban dari skema Kombinasi lebih tinggi daripada total beban pada skema MBLS. Dan besarnya nilai perbaikan yang dihasilkan adalah sekitar 4,72\%. Beban paging sebanding dengan banyaknya panggilan yang datang dan lokasi terakhir kali MS melakukan location updating.

Mekanisme Paging (searching) harus digali lagi guna mendapatkan metode yang lebih efisien untuk pencarian MS (searching cost), antara lain dengan membagi area paging ke dalam sejumlah sub-area. Beban location updating dan paging sebaiknya ditentukan juga oleh beban per selnya. Perlu adanya kajian lebih dalam mengenai metode location updating yang berdasarkan distance (jarak), sehingga penelitian mengenai manajemen lokasi akan semakin lengkap.

\section{Daftar Pustaka:}

[1] Akyldiz, I. F. and J. S. M. Ho. 1996. On Location Management for Personal Communications Networks. IEEE Communications Magazine.

[2] Akyldiz, I. F., J. Ho, and B. L. Yi. 1996. Movement Based Location Update and Selective Paging for PCS Network. IEEE/ACM Trans. On Networking, Vol. 4, pp 629-638.

[3] Has, A. 1998. Database and Location Management Schemes for Mobile Communications. IEEE/ACM Trans. On Networking, Vol. 6, No. 6.

[4] Lee, W. C. Y. 1995. Mobile Cellular Telecomunications. McGraw-Hill International Edition.
[5] Li, J., H. Kameda, and K. Li. 2000. Optimal Dynamic Mobility Management for PCS Networks. IEEE/ACM Trans. On Networking, Vol. 8, No. 3.

[6] Mouly, M. and M. Pautet. 1992. The GSM System for Mobile Communications.

[7] Supranto, J. 1993. Statistik Teori dan Aplikasi Jilid 2. Erlangga.

[8] Training Departement European Cellular Infrastructure Division. 1996. Introduction To Digital Cellular. Motorola Ltd. 